\title{
Social investment conflicts related to the construction of the A1 motorway in the Silesian voivodeship (Southern Poland)
}

\author{
Adam Hibszer \\ Department of Physical Geography, Faculty of Earth Sciences, University of Silesia, Będzińska 60, 41-200 Sosnowiec, Poland \\ E-mail address: adam.hibszer@us.edu.pl
}

\begin{abstract}
Motorway construction poses various problems, both in green fields, mainly because of concerns about the natural environment, as well as in brown fields, for technical reasons and due to disturbing residents. The Silesian voivodeship is one of the particularly problematic areas. The construction of the A1 motorway is not an easy task there. It is not only because of the potential changes in the environment or difficulties in conducting construction work in mining areas, but also because of the highly urbanised area, requiring both the compulsory purchase of land, as well as demolition of housing infrastructure. The aim of the study is to present the most serious conflicts related to the construction of the A1 motorway in the Silesian voivodeship. The method used in the study was the analysis of documents related to its construction from the websites of the General Directorate for National Roads and Motorways (Generalna Dyrekcja Dróg Krajowych i Autostrad - GDDKiA), the Voivodeship Office in Katowice and evaluation of information from the websites of communities in which the motorway investments were carried out. Moreover, voivodeship electronic editions of magazines and daily newspapers from the years 2006-2013 on the disputes arising from the construction of the A1 motorway were reviewed. As a result of the study it was found that for different sections of the motorway social conflicts occurred. They were diverse in nature, extent and the course. The analysis of the results shows that the implementation of this type of investment requires not only financial expenses and studies on the environmental impact, but also activities involving their social environment.
\end{abstract}

KEY WORDS: motorway, social conflict, risk of road investments

\section{Introduction}

Communication investments, like any kind of infrastructure investments in the environment, usually arouse protests of the population (BonILLA, 2010; FRIEDMAN-RUDOVSKY, 2010; HABER, 2007; MATCZAK, 1996; NEW PUBLIC ROAD, 2010; NOWAK, 2001; TEISTER, 2012; ZIELIŃSKA, 2009). The antagonistic relationship between stakeholders is often the cause of violent conflicts (DEUTSCH, 1998; DEUTSCH \& COLEMAN, ed., 2005). They are the result of actual or alleged conflicts concerning the investment's function (BAŃSKI, 1999; GROCHOLSKA, 1980) or objectives (KoŁODZIEJSKI, 1982a; ZUZIAK, 1995). Consequently, they lead to differences in social behaviour in relation to specific changes in spatial planning, as well as to assessment of the impact of these changes in the values of the environment
(ZUZIAK, 1995). As the subjects of the conflicts are changes in the use of space, hence planners and geographers call them spatial, functional-spatial or localisation conflicts (GROCHOLSKA, 1980; KoŁoDZIEJSKI, 1982a). Among the many definitions of conflicts of space, including KOŁODZIEJSKI (1982b), KWAŚNIEWICZ (2000), SZTUMSKI (1987), ZUZIAK (1995), the one that captures well the essence of the issue is the definition proposed by SŁABON (2008). According to this author, the process of interaction between stakeholders (parties), which are aware of the actual or imaginary incompatibility of objectives and interests that seek to force a change of taken or intended action of the other party and/or to harm the opponent, is called a social conflict. A conflict can be a useful provocation to clarify positions, and sometimes the lack of clarity is a more important cause of the 
dispute than the cause itself (PAWŁOWSKA, 2008b). A conflict triggers ingenuity, which can be used not only to fight, but also to achieve a new better solution (CHEŁPA \& WITKOWSKI, 1999). The disclosure of the unadmitted or ignored conflict opens the way towards its solution (MCKAY ET AL., 2001).

In this study collisions of interests and misunderstandings between stakeholders and, consequently, social conflicts caused by a new investment in the area - the construction of the motorway - are called social investment conflicts. The demarcation of new routes (especially the A1 motorway and expressways) in the area of the Silesian voivodeship creates many problems. Natural hazards associated with both the road construction phase, as well as with the later phase of their operation (FAJER, 2005; RAPORT..., 2007; SZCZYPEK \& WACH, 1996), are accompanied by problems arising from the presence of the mining areas and the fact that the area is covered with densely-built housing estates (blocks of flats or detached houses). In addition to interfering with the natural environment, such investments require the compulsory purchase of land, often demolition of buildings and, as a result, the population displacement. The scale of these difficulties is confirmed by many years of studying variants of individual roads. Each of the proposed variants of such an investment, because of the clash of interests between investors and owners of the land through which they are to be routed, may cause potential conflicts.

The work on determining the course of the transportation routes across the Silesian voivodeship (especially roads of national or even European importance, as is the case of the motorway) is actively participated by the local authorities from the Local Government Council of the Silesian Voivodeship, the heads of towns, cities and communities, as well as the Silesian Voivode as a representative of the government. The voice is also taken by the State Forests, environmental organisations and, increasingly, active local communities, mainly through associations formed in order to fight for a change in the route or complete blockage of the project.

\section{The course of the A1 motorway across the Silesian voivodeship}

The A1 motorway is part of the international route E75, starting in the northern part of Norway (in the town of Vardø) and goes across Finland, Poland, Czech Republic, Slovakia, Hungary, Serbia and Macedonia to Greece (to the town of Sitía on Crete) (Fig. 1A). It is a European motorway of the meridional course, of the planned length of about $600 \mathrm{~km}$ in the area of Poland. At the Stryków Junction north of Łódź it will cross the A2 motorway, while at the Sośnica Junction in Upper Silesia - the A4 motorway.

The section of the motorway going through the Silesian voivodeship (Fig. 1B) is to have a length of over $230 \mathrm{~km}$. At the moment (as of June 2013) in the Silesian voivodeship there exists, and is fully operated, the middle 79-kilometre stretch between Świerklany near Żory and the Pyrzowice Junction. The southern part of the motorway (about $17 \mathrm{~km}$ ), i.e. from the border with the Czech Republic to the Świerklany Junction, is officially "in progress" (Fig. 2), i.e. starting from December 2012 cars can drive on it, with the exception of about 11-kilometre fragment of the route near the defectively constructed bridge in Mszana (Fig. 3).

The bypass of the closed section of the motorway is routed along the voivodeship roads. It is planned to complete this section is June 2014. In contrast, the missing stretch of more than $120 \mathrm{~km}$ north from the Pyrzowice Junction to Tuszyn in the Łódzkie voivodeship is in the preparatory phase. A tender for its construction is to start in 2013. It is planned to complete its construction in 2016.

The construction of the A1 motorway across the Silesian voivodeship is among the priority investments performed in stages in the licensing system. Both at the stage of designing the road route, as well as the construction in its southern sections of Sośnica - Bełk, Bełk - Świerklany and Świerklany - Gorzyczki did not go without the disputes with the inhabitants of the towns and villages through which the motorway passes.

\section{Characteristics of conflicts}

\subsection{Conflict about the Żory - Rowień route of the A1 motorway}

According to the GDDKiA data, the route of the Sośnica - Gorzyczki section follows the variant of the project which causes the least collisions. The location indications were issued on 31 December 1999 by the Minister of Internal Affairs and Administration. They imposed a requirement for establishing the detailed course of the motorway due to the needs of the mining industry as well as the arrangements with the Directorate of the Landscape Park "Cistercian Landscape Compositions of Rudy Wielkie". These conditions were met in the documentation for the location decision of the A1 motorway at this section. 


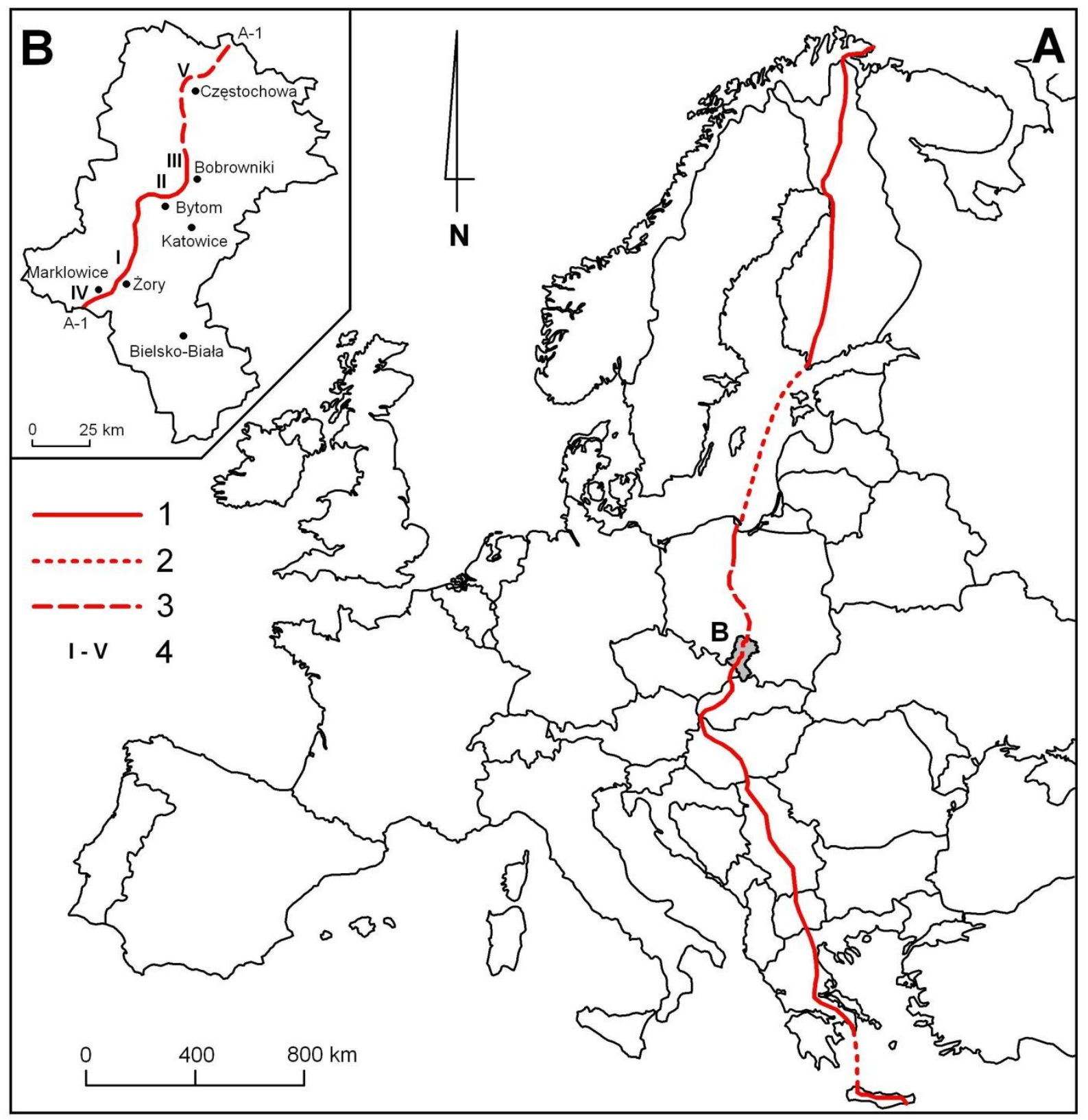

Fig. 1. The A1 motorway in Poland as a part of the international route E75 (A);

The A1 motorway in the Silesian voivodeship (B)

1 - motorway open; 2 - ferry; 3 - motorway construction; 4 - places of social conflicts caused by construction of the A1 in the Silesian voivodeship (numbering in the figure corresponds to the description in the text)

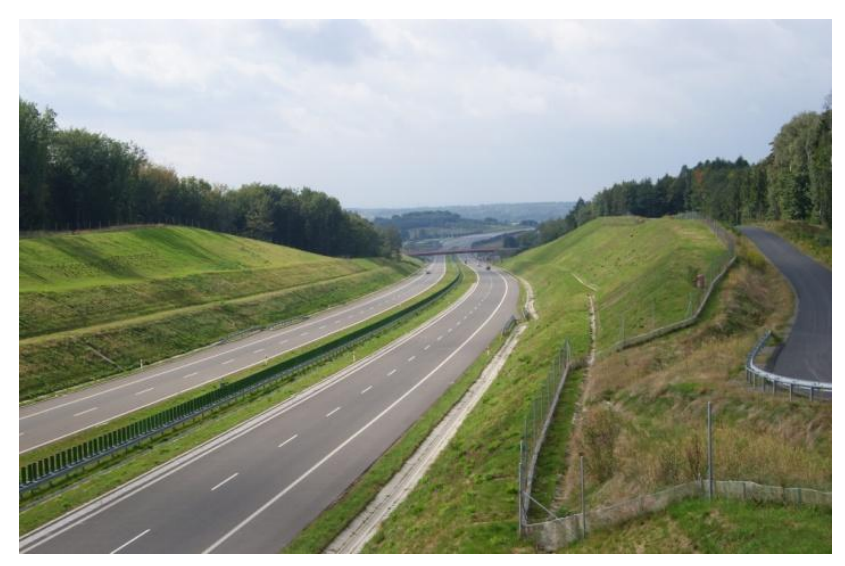

Fig. 2. The A1 motorway at the border of the communities Godów and Mszana - photo made the north of the bridge on 1 Maja Street in Mszana (T. Dulias)

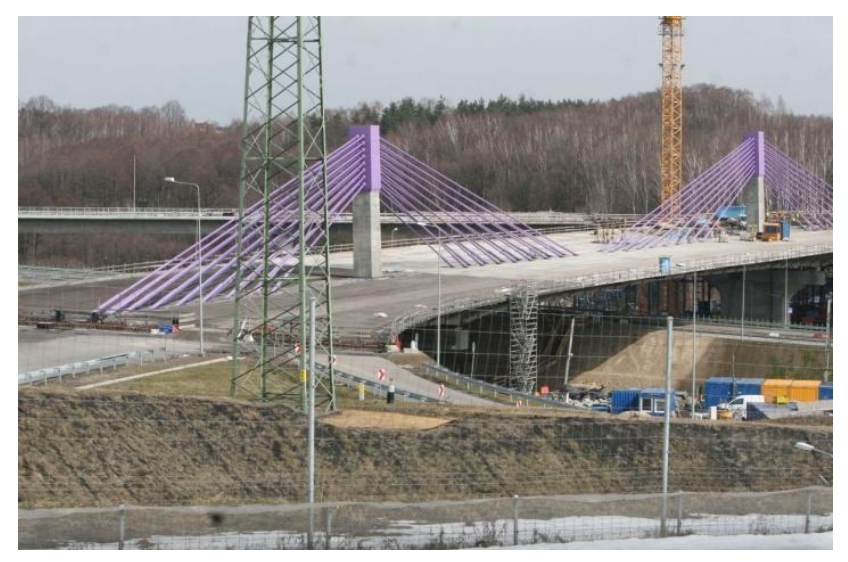

Fig. 3. The defectively constructed bridge in Mszana (archives GDDKiA) 
In accordance with the law the course of the A1 motorway, also through Żory - Rowień, was positively consulted by the Mayor of Żory. On 3 April 2003, the Voivode of Silesia issued three location decisions for the motorway sections Sośnica - Bełk, Bełk - Świerklany and Świerklany - Gorzyczki. Applications for the decision were preceded by consultations required by the law and supplemented to date opinions, which was also publicised for the local community.

However, after issuing the decision a conflict broke, as residents of Rowień, a district of Żory, proposed changing the route in a way that could reduce the number of demolition of private houses in the area. The variant proposed by the Protest Committee of the Residents of the Żory Districts Rowien and Folwarki was incompatible with all earlier indications of localisation and agreements with the community of Żory and the Directorate of the Landscape Park "Cistercian Landscape Compositions of Rudy Wielkie".

According to the investor the solution proposed by the residents of Rowien would lead to demolition in the district of Kłokocin. In addition, the location does the motorway in the valley of the river Kłokocinka would be linked to the construction of very expensive strengthening systems, and would involve constructing the road along a high embankment to cross the road No. 935 Pszczyna - Racibórz, which in turn would increase the burden because of the extent of noise.

The decision of 3 April 2003 for the section of Bełk - Świerklany was appealed to the Minister of Infrastructure, who upheld the location decision. Representatives of the Żory - Rowień residents, disagreeing with this statement, lodged a complaint with the Voivodeship Administrative Court in Warsaw. On 14 October 2005 the Court dismissed the complaint on establishing the location of the motorway. From that court judgement the representatives of the inhabitants of Rowien filed a cassation complaint to the Supreme Administrative Court in Gliwice, which dismissed it on 27 June 2006.

Since all the legal remedies were exhausted and the location decision became final, the investor took measures to accelerate the investment. The location decision was not affected by interest of local politicians who tried to support the activities of the inhabitants (JANIK, 2006; STOMMA, 2006). Due to general social interest connected with the planned construction the work was carried out according to the previously adopted plans.

On 12 July 2006 at the City Hall in Żory an additional meeting of councillors and residents of Żory was held. It involved the vice-Voivode of Silesia and the Director of the Department of the
GDDKiA and was on the route of the motorway through the district Żory - Rowień. Some participants of the meeting demanded change of the decisions and purchase of land reserved for more than 30 years (outside the approved project). The representatives of the authorities recognised that attempts to change the decision on the location of the motorway are not rationally justified. Despite the opposition of the local community the construction work of the motorway was undertaken according to the earlier adopted plans.

There were, however, crises situations during the construction of this section of the motorway. Until the end of June 2009, at the advanced construction site, a long-lasting dispute concerned one house in Żory - Rowień (previously 65 houses were demolished). The owners refused to move out voluntarily. The case went to the Voivode of Silesia, who initiated the compulsory purchase procedure. It seemed that, for the first time in the history of the Silesian section of the A1, the force will have to be used. Finally, at the end of June 2009, the GDDKiA in Katowice came to an agreement with the owners of the property, who moved to alternative accommodation and the house was demolished. The owners were offered higher compensation than the first time, as their agricultural land and the house were priced separately (GŁOGOWSKI, 2009).

\subsection{Conflict about the A1 motorway route through Bytom (II)}

The first indication of the location of the motorway through Bytom was issued in 1999. It was the so-called northern variant. The project assumed that five houses would have to be demolished. Then the Society for the Development of Stolarzowice and Górniki awakened; it sets itself the goal of moving the A1 outside the district. Over time the new authorities of the Society supported the change in the route in favour of the so-called southern variant. The project of the A1 motorway section running through the area of the Stolarzowice district was approved by the City Council in Bytom, which in this case signed the resolution of 28 August 2002. The council decided this variant was better for implementation. This change divided the inhabitants of Stolarzowice into two hostile camps (NOWAK, undated).

The southern route of the motorway A1 through Bytom was approved by the decision issued by the Voivode of Silesia on establishing its location on 27 September 2005. This decision became final on 25 October 2006, together with the decision of the Minister of Infrastructure, issued on the 
basis of so called special motorway law, aimed to accelerate the construction of motorways in Poland. Compensation for compulsory purchase was paid to a few people who left their houses which were to be demolished during the motorway construction. Fifty ha of forest was cut down in the course of the future motorway. Meanwhile, it turned out that the change of the indicated localisation from the northern to the southern variant had not been confirmed by an official localisation decision (WROŃSKI, 2009).

In 2007, one of the residents of Stolarzowice appealed against the location decision to the Voivodeship Administrative Court in Warsaw. After two years, on 11 March 2009, the court quashed the decision of the Minister on the course of the A1 in Bytom. The court took the view that the ministry did not complete the procedure and did not indicate the changes from the northern to southern localisation, so the very decision was taken on the basis of a non-existent indication. In accordance with the judgment of the Voivodeship Administrative Court in Warsaw on the route of the motorway $\mathrm{A} 1$ through the area of Bytom, there emerged a group of people who put forward the "civic" project changing the route of its course. According to it, the motorway bypasses the houses and goes from Dąbrowa Miejska to Górniki, and further to Zabrze. The citizens of Stolarzowice hoped that the authorities of Zabrze and Bytom would come to an agreement in this case and it would be possible to change the route of the A1. However, changing the route of the motorway according to this project would require cutting down the forest in the area three times larger than it has already been done. This would lead to the destruction of the ecosystem of Bytom and the devastation of the valleys "Pańskie Łąki" and "Zielone Doliny", i.e. the natural enclaves of Zabrze.

The proposal of the Stolarzowic residents was disapproved by the representatives of the Association for the Protection of Forest Bytom. On 4 June 2009 they turned to the Voivode of Silesia with an appeal to oppose the initiative. In the opinion of the Association the correction of the motorway's route according to the "civic" project would result not only in the devastation of nature but would be an example of economic waste (AUTOSTRADA POWSTAJE ..., 2009).

The residents of Stolarzowice, who did not accept the route of the motorway by their houses, announced they were going to block the construction site of the motorway and intervene with the Voivode of Silesia in the hope of changing its course. They also announced they will do everything to return the case back to the magistrate of Bytom, where the course of the road would need to be re-thought. Since the court did not question the route of the motorway in Bytom, but only drew attention to the poor justification of the Minister of Construction related to changes in the route, the road has been conducted according to the plans of the GDDKiA.

\subsection{Conflicts about the construction of the A1 motorway through the community of Bobrowniki (III)}

Social conflicts also accompanied the construction of the A1 motorway at the stretch of Piekary Śląskie - Pyrzowice and the linked S1 expressway to the airport in Pyrzowice. The hottest disputes with the GDDKiA were conducted by the residents of Siemonia and Sączów in the community of Bobrowniki. The Association "Siemonia - Past Present Future", specially organised for this purpose, sent rich correspondence to the GDDKiA, the Marshal's Office, the Voivode of Silesia, Water Management, Office of the Ombudsman, Insurance Ombudsman, Voivodeship Inspector of Construction and many other institutions. In the correspondence the residents repeatedly complained about numerous nuisances arising from the road construction.

In the letters one can read about "The increased road transit, overloaded trucks on our roads, damaged street pavements, muddy roads - these are just some of the burden and risks to which we are condemned, and we will be, unfortunately, in the following years. Violation of water conditions along the motorway under construction created additional risk of flooding for many residents of Siemonia and Saczów who are still struggling with the effects of the rising groundwater table. Constantly, even in the absence of precipitation, water discharged from the motorway lane infiltrates and floods houses. This additional risk of flooding looms large in the minds of not only the victims, often already exhausted by the fight against soulless bureaucracy and incompetent officials, but also the authorities of the community and most of all our Association, which actively participated in helping our residents. There is no way to live in such conditions!";"In May this year (2012) we will have faced two years (!!!!) since the residents of Wolności Street in Siemonia and Saczów have been unsuccessfully fighting against the GDDKiA for compensation for persistent flooding of residential buildings, due to the construction of the A1 motorway and impaired functioning water conditions of the adjacent areas." (website of the Association Siemonia - Past Present Future, accessed in June 2013).

Numerous official letters and rich photographic documentation, minutes of local vision and the 
expertise of specialists in the field of water law did not produce any effect. To prove and illustrate the change in the hydrogeological regime and groundwater table as a result of the nearby construction of the A1 motorway, adjacent to flooded properties, five piezometers were installed. Such a recommendation was issued by the authors of the hydrogeological and hydrological expertise conducted in the area of the flooding in June 2011. Unfortunately, despite strenuous requests of the inhabitants, the budget of the community did not guarantee financial resources for constant observation of the groundwater table (website of the Association Siemonia - Past Present Future, accessed in June 2013).

Observing the determination of the residents of the said villages in the community of Bobrowniki (who also feel threatened by the project of building a railway line linking Katowice with the Airport in Pyrzowice), it can be assumed that the disputes with the GDDKiA will also take place in the future, i.e. after the opening of this stretch of the motorway, at any increase of the groundwater table resulting in flooding the area of the community.

Formal completion of the construction of that section of the motorway though the community of Bobrowniki in January 2012 did not end the problems for the community inhabitants. It soon turned out that the cause of another dispute with the GDDKiA was the transport of materials from the construction site, and - according to the residents of the community of Bobrowniki - their illegal storage in a few places in the community. According to the website www.bedzin.naszemiasto.pl, for over a month the roads of Siemonia and Twardowice were used for transporting waste ground from the construction of the A1 in Myszkowice towards Góra Siewierska.

Daily, multiple heavy equipment runs caused destruction to and muddied local roads leading out of the completed construction across the centres of the villages to the storage places of the waste ground. As in many sections, these streets required urgent repair, not just patching the holes, but in fact the constructing new pavement, the residents intervened in this case at the District Office in Będzin which is the disposer of these roads. By the end of 2012 the road had been repaired, as indeed was provided in the schedule of the construction works.

Such work significantly intensified after gaining financial aid: nearly one million PLN from the budget of the community of Bobrowniki for the poviat to improve the road infrastructure. In addition, the court was notified of an offence concerning illegal dumping of waste on private land in Twardowice and Rogoźnik (community of Bobrowniki) and Góra Siewierska (community of Psary) because the District Office did not permit any waste storage.

The staff of the Department of Environment and Forestry of the District Office informed the Marshal's Office in Katowice about the issue. The whole matter was complicated by the fact that the owner of the transport company ZRB Ossy had a permit to transport "waste" and the agreements with the owners of the plots on which it was stored. The checks revealed no irregularities in this regard. The law states that the owners of the plots are obliged to report it to the District Office, and the owner of the transport company undertook to repair the damage caused to the roads.

\subsection{Conflict about the A1 motorway bypass in Marklowice (IV)}

The conflict connected with the A1 motorway in Marklowice was quite different in nature. This time, the dispute resulted from the discontinuation of work on completing the construction of the motorway, i.e. the bridge in Mszana. In autumn 2012, the ministerial decision was taken to make the southern section of the A1 motorway from Świerklany to Gorzyczki available for cars. In connection with the unfinished bridge in Mszana, the traffic was introduced to more than 10-kilometre motorway detour from the Junction in Mszana to the Junction in Świerklany along the voivodeship roads 932, 939 and 933.

From the very beginning the temporariness of this solution was not accepted by the inhabitants of the nearby villages located on the route designated for transit traffic. Bad road condition, no shoulders for pedestrian traffic and the high density of the single-family housing resulted in monthly protests of the residents. They involved several hours of blocking the car traffic on pedestrian crossings in Świerklany on the route 932. Every quarter about 50 protesters left the pedestrian crossing for a few minutes.

In the event of a protracted recovery process of the unfinished bridge in Mszana, accepting the temporary state of the detours along local roads, the residents demanded at least the repair of roads and the construction of the pavement towards Marklowice. As a result of the protests and bad technical condition of the road, the pavement of which was so deformed that threatened the safety of those using it, at the beginning of September 2013 the through traffic along the voivodeship road 932 between 
Świerklany and Marklowice was stopped in favour of the transit route DK 78 through Rybnik (Wójt MSZANY... 2013).

\subsection{Conflict about the "Częstochowa" section of the A1 motorway (V)}

The conflict about the "Częstochowa" stretch of the motorway was of a different nature than those presented above. This is the last section of the A1 in the Silesian voivodeship, the construction of which has not even started. In this case the primary dispute does not concern the route, but the funds for the implementation of the road. The conflict is between the local authorities and the Ministry of Transport. A few years ago the project of the Spanish-Polish consortium was not realised as it contained numerous errors. In addition, the consortium did not gather sufficient funds for the investment (KIEDY ZNIKNIE... 2013).

Currently a new project has been developed, commissioned by the GDDKiA, but there is a lack of funds for its implementation. Although the European funds intended for the construction of new roads were unblocked by Brussels in March 2013, the Ministry of Transport has not directed them to implement this section of the motorway. In the explanation the EU conditions were quoted, which showed that it does not subsidise investments that in the future (after putting the toll motorway to use) will generate high profits from the fees due to the expected high traffic on the motorway.

In this situation, the Silesian Marshal's Office suggested that the government included the Piotrków - Czestochowa - Pyrzowice motorway stretch in so called government contracts for the years 2014-20. This new formula is to include investments financed by the government, also road construction, but coordinated with the projects planned by individual voivodeships. In this case, the money will come from the EU budget for the years 2014-20, but the national financial resources will also be taken into account. In this scenario, in the case of the A1, it may therefore involve only national resources. In contrast, the government has a different solution for the Częstochowa motorway: it is not going to wait for the signing of territorial contracts (which need to be negotiated), and the Częstochowa A1 is to be dealt with by a government company The Polish Investments. The projects are to be financed by the extra privatisation, i.e. the sale of some shares of the state-owned companies. It is not clear which option will finally be adopted. With the intention to tender for the construction works still in 2013, it is likely the work will begin already in 2014 (JEST PROJEKT..., 2013).

\section{Discussion of the results}

Every road investment has a certain proximity for which it is more or less burdensome. In the case of large infrastructure investments, such as communication routes, it usually happens that the direct benefit to the immediate environment is non-existent or very small, e.g. motorways run through the area which is not provided with the access roads. In such situations conflicts often erupt, which can be described as "neighbourhood disputes". The "victim" side is the residents of the areas surrounding the investment, causing all sorts of nuisance or danger.

In such situations a reaction often takes place, which is referred to with an acronym NIMBY "not in my backyard" - which expresses the position and behaviour adopted by the residents of the neighbourhood of investments: "Build it where you want, but not here. Maybe it is needed, maybe the society needs it, but not here - we want to live in peace" (INWESTYCJE INFRASTRUKTURALNE, 2008). A review of the specialist literature, including the work of researchers dealing with this issue, e.g. MATCZAK (1996) and DMOCHOWSKADUDEK (2011), it is known that the people who participate in such conflicts, in principle, do not question the need to build a given investment; they only do not want it to be located in their environment. The above conflicts characterised in detail are linked through the fact that they all refer to the construction of the Silesian section of the A1 motorway. In most cases, sides of litigation were the inhabitants of towns and villages in which the investment and construction took place and the GDDKiA. They differ in many other aspects: the subject of the dispute, its duration and the form of protest (Tab. 1). The conflicts occurred both in the period preceding the start of construction work (conflict situations No. I, II and $\mathrm{V}$ ), in the course of their implementation (conflict situations No. I, III and IV), and after its implementation (conflict situation No. III). The results of this study allow observing serious negligence of the investor, i.e. the GDDKiA, in the field of social communication in relation to local communities which were directly related to the investment.

The conflict cases around the A1 recall situations known from the specialist literature (BonILLA, 2010; FRIEDMAN-RUDOVSKY, 2010; HABER, 2007). In the cited studies relating to the conflict situation related to the construction of communication routes, regardless of where in the world the investment is carried out, the authors also pointed out numerous deficiencies in the 
process of social communication in relation to the local population. In contrast, many other authors dealing with social conflicts, i.a. BURGER (1999), KALINOWSKA (2007), SZTUMSKI (1987), stress the importance of the position of the local population in the case of the investment which may impact their lives. It may be simply said that the participation of a local community in relation to the course of the construction should be an important element of the decision-making process.

Table 1. Comparison of conflicts related to the construction of the A1 motorway through the Silesian voivodeship (made by author)

\begin{tabular}{|c|c|c|c|c|c|}
\hline $\begin{array}{c}\text { No of } \\
\text { conflict }\end{array}$ & Conflict sides & Conflict issue & Duration & Conflict form & Position of the GDDKiA \\
\hline I & $\begin{array}{l}\text { Residents of Rowien - } \\
\text { the GDDKiA }\end{array}$ & $\begin{array}{l}\text { the route through } \\
\text { Rowien - the part of } \\
\text { Żory }\end{array}$ & $\begin{array}{l}1999- \\
2009\end{array}$ & $\begin{array}{l}\text { appeal to the } \\
\text { Minister of } \\
\text { Infrastructure } \\
\text { and the Supreme } \\
\text { Administrative } \\
\text { Court }\end{array}$ & $\begin{array}{l}\text { to construct the road } \\
\text { according to the approved } \\
\text { project without taking into } \\
\text { account the proposals of the } \\
\text { residents; higher } \\
\text { compensation for the } \\
\text { demolished house in the case } \\
\text { of one owner }\end{array}$ \\
\hline II & $\begin{array}{l}\text { Residents of } \\
\text { Stolarzowice - } \\
\text { (Association of } \\
\text { residents and } \\
\text { individuals) - the } \\
\text { GDDKiA }\end{array}$ & $\begin{array}{l}\text { the route through } \\
\text { Stolarzowice - } \\
\text { the part of Bytom }\end{array}$ & $\begin{array}{l}1999- \\
2010\end{array}$ & $\begin{array}{l}\text { interventions } \\
\text { with the Voivode, } \\
\text { the submission of } \\
\text { the case in the } \\
\text { Administrative } \\
\text { Court }\end{array}$ & $\begin{array}{l}\text { to construct the road } \\
\text { according to the approved } \\
\text { project }\end{array}$ \\
\hline III & $\begin{array}{l}\text { Residents of Siemonia } \\
\text { and Sączów in the } \\
\text { community of } \\
\text { Bobrowniki (residents' } \\
\text { association) - the } \\
\text { GDDKiA }\end{array}$ & $\begin{array}{l}\text { nuisance arising } \\
\text { from the construction } \\
\text { of the road - the } \\
\text { destruction of local } \\
\text { roads, flooding the } \\
\text { property, disposal of } \\
\text { waste from the } \\
\text { construction site } \\
\end{array}$ & $\begin{array}{l}2010- \\
2012\end{array}$ & $\begin{array}{l}\text { written complaint } \\
\text { on the investor to } \\
\text { various entities, } \\
\text { among others, the } \\
\text { voivodeship } \\
\text { authorities, filing } \\
\text { a case in court }\end{array}$ & $\begin{array}{l}\text { to finance the repair of } \\
\text { damaged roads in accordance } \\
\text { with the approved schedule } \\
\text { of work }\end{array}$ \\
\hline IV & $\begin{array}{l}\text { Residents of } \\
\text { Marklowice and } \\
\text { Świerklany - } \\
\text { the GDDKiA }\end{array}$ & $\begin{array}{l}\text { failure to complete the } \\
\text { construction of the } \\
\text { motorway (a bridge } \\
\text { in Mszana) and } \\
\text { introducing detours } \\
\text { along local roads }\end{array}$ & $\begin{array}{l}2012- \\
2013\end{array}$ & $\begin{array}{l}\text { roadblocks on } \\
\text { pedestrian } \\
\text { crossings }\end{array}$ & $\begin{array}{l}\text { transit routing went along } \\
\text { the less onerous voivodeship } \\
\text { road through Rybnik }\end{array}$ \\
\hline V & $\begin{array}{l}\text { Local authorities - } \\
\text { the Ministry of Transport }\end{array}$ & $\begin{array}{l}\text { financial resources for } \\
\text { the implementation } \\
\text { of the road }\end{array}$ & $\begin{array}{l}2009- \\
\text { continued }\end{array}$ & $\begin{array}{l}\text { dispute between } \\
\text { the centres of } \\
\text { power }\end{array}$ & no decision \\
\hline
\end{tabular}

The above descriptions of social investment conflicts caused by the construction of the A1 motorway certainly do not include all such events taking place in recent years in the Silesian voivodeship. They only concern the most wellknown situations publicised by the media. One should be aware that any communication investment may cause the opposition of a person or persons who had imagined a different development of the area. It can also be taken as a pretext to express dissatisfaction and, in consequence, to the formation of a dispute with the investor.

\section{Conclusions}

The results of the study allow drawing the following conclusions: 1) road investments, especially of the regional and national importance, generally trigger opposition among people whose land and homes are subject to any threats, sometimes demolished, or who face deterioration in the quality of life due to the location of such an investment in the vicinity; 2) preparation and implementation of communication investments in such heavily urbanised area as the Silesian voivodeship is a difficult and complex task. Many of the problems that have to be solved are of a social character. In the case of social conflicts, the investor must be prepared to solve them skilfully; 3) the implementation of each communication investment must be closely linked to the diagnosis of its social environment. Measures undertaken by the investor should include actual, and not pretended, cooperation of stakeholders interested in its implementation. Only honest communication with the public is a guarantee of the conflict-free success. 


\section{References and sources}

Autostrada powstaje wzdłuż granicy Zabrza. Nowiny Zabrzańskie (10.06.2009).

Bański J. 1999. Obszary problemowe $w$ rolnictwie Polski. Prace Geogr., 172, IGiPZ PAN, Warszawa.

Bonilla 0. 2010. The Manta-Manaos project: nature, capital and plunder - acción ecológica - Ecuador. http:// www.ceecec.net/case-studies/manta-manaos

Burger T. 1999. Konflikt i współdziałanie. Świadomość ekologiczna i postawy społeczeństwa. [in:] Mirowski W. (ed.) Świadomość ekologiczna i społeczne ruchy „zielonych” $w$ Polsce. IFiS PAN, Warszawa: 35-55.

Chełpa S., Witkowski T. 1999. Psychologia konfliktów. Praktyka radzenia sobie ze sporami. Wyd. UNUS, Wrocław.

Deutsch M. 1998. Constructive Conflict Resolution: Principles, Training, and Research. [in:] Weiner E. (ed.) The Handbook of Interethnic Coexistence. Continuum Publ., New York: 199-216.

Deutsch M., Coleman P.T. ed. 2005. Rozwiq̨zywanie konfliktów. Teoria i praktyka. Wyd. UJ, Kraków.

Dmochowska-Dudek K. 2011. Obiekty NIMBY jako przykład konfliktowych inwestycji na terenach mieszkaniowych teoretyczny zarys problemu. [in:] Dzieciuchowicz J. (ed.) Współczesne przemiany środowiska mieszkaniowego wybrane problemy. Space-Society-Economy, no 10, Wyd. UŁ, Łódź: 29-56.

Fajer M. 2005. Autostrada A-1 a środowisko przyrodnicze Parku Krajobrazowego „Cysterskie Kompozycje Krajobrazowe Rud Wielkich” w okolicach Szczejkowic. [in:] Hibszer A Partyka J. (eds.) Między ochronq przyrody a gospodarkq, bliżej ochrony. Konflikty człowiek - przyroda w obszarach prawnie chronionych $w$ Polsce. Oddz. Katowicki PTG, Ojcowski Park Narod., Sosnowiec - Ojców: 164-172.

Friedman-Rudovsky J. 2012. In Bolivia, a battle over a highway and a way of life. YALE Environment 360. http://e360.yale.edu/feature/in_bolivia_a_battle_over_a_ highway_and_a_way_of_life/2566/27.08.2012

Głogowski T. Samotny dom na autostradzie A1 został zburzony. http://katowice.gazeta.pl/katowice/1,35063,6762797, Samotny_dom_na_autostradzie_A1_zostal_zburzony.html (29.05.2010).

Grocholska J. 1980. Obszary konfliktowe - problem badawczy w przestrzennym zagospodarowaniu kraju. Przegl. Geogr., 52, 3: 507-517.

Haber E. Rospuda - dolina niezgody. Polska gazeta Transportowa, http://archive.is/sJR0r (4.05.2013).

Inwestycje infrastrukturalne. Komunikacja społeczna $i$ rozwiqzzywanie konfliktów. Minist. Rozwoju Region., Warszawa, 2008. http://www.popt.gov.pl/dzialania promocyjne/Documents/POPT_Podrecznik_komunikacji _071108.pdf

Janik G. Interpelacja $n r 4180$ do ministra transportu w sprawie zmiany kształtu węzła autostrady A1 w Żorach Rowniu (03.07.2006) http://www.gover.pl/y=/poslowie/ szczegolyInterpelacji/posel/janikgrzegorz/interpelacja/int erpelacja-w-sprawie-zmiany-ksztaltu-wezla-autostrady-a1w-zorach-rowniu/ (29.05.2010).

Jest projekt autostrady A1 na północ od Pyrzowic. Dzien. Zach. (11.01.2013).

Kalinowska A. 2007. Komunikacja ze społeczeństwem delikatny klucz do zarządzania ochroną środowiska. [in:] Kalinowska A., Lenart W. (eds.) Wybrane zagadnienia $z$ ekologii $i$ ochrony środowiska. Teoria i praktyka zrównoważonego rozwoju. Uniw. Warszawski. Uniw. Centrum Badań nad Środ. Przyrod., Warszawa: 295-301.
Kiedy zniknie „częstochowska dziura” na A1. Przetarg może będzie w tym roku. Gazeta.pl. Częstochowa (16.04.2013).

Kołodziejski J. 1982a. Geneza, funkcjonowanie oraz ocena sytuacji konfliktowych w gospodarce przestrzennej Polski. [in:] Diagnoza stanu gospodarki przestrzennej Polski. Biul. KPZK PAN, nr 123.

Kołodziejski J. 1982b. Realizacja celów rozwoju w warunkach narastania konfliktów w gospodarce przestrzennej. [in:] Konflikty polskiej przestrzeni. Biul. KPZK PAN, nr 120.

Kwaśniewicz W. 2000. Konflikty społeczne w dobie zmiany ustrojowej a procesy żywiołowe. [in:] Malikowski M., Seręga Z. (eds.) Konflikty społeczne $w$ Polsce $w$ okresie przemian systemowych. Studia, komunikaty, eseje, t. I, Wyd. Wyższej Szkoły Pedagogicznej, Rzeszów.

Ludzie znowu zablokowali droge. Nie chcq objazdu. http:// katowice.gazeta.pl/katowice/0,120231.html?tag=autostrad a+a1 (26.07.2013).

McKay M., Davis M., Fanning P. 2001: Sztuka skutecznego porozumiewania się. Gdańskie Wyd. Psych., Gdańsk

Matczak P. 1996. Społeczne uwarunkowania eliminacji syndromu NIMBY. [in:] Cichocki R. (ed.), Podmiotowość społeczności lokalnej. Poznań.

New Public Road to Split the Serengeti? 2010, http://www. savetheserengeti.org/issues/highway/stop-the-serengetihighway/(2013).

Nowak M. 2001. Protesty lokalizacyjne jako egzemplifikacja zmiany systemowej połowy lat dziewięćdziesiątych. [in:] Buczkowski P., Matczak P. (eds.) Konflikt nieunikniony. Wspólnoty i władze lokalne wobec konfliktów spowodowanych rozwojem. Wyd. Wyższej Szkoły Bankowej, Poznań.

Nowak T. (undated) Mamy problem $\mathrm{z}$ autostradą. Bytom będzie przecięty trasą A1. Tylko nikt nie wie, jak. Życie Bytomskie http://www.zyciebytomskie.pl/artykul.php?id= 179 \&glowny $=1(29.05 .2010)$.

Pawłowska K. 2008. Przeciwdziałanie konfliktom wokół ochrony i kształtowania krajobrazu. Partycypacja społeczna, debata publiczna, negocjacje. Wyd. Politech. Krakowska im. T. Kościuszki, Kraków.

Raport o oddziaływaniu przedsięwzięcia na środowisko Autostrada A1 odc. Pyrzowice (bez węzła) - Maciejów (bez

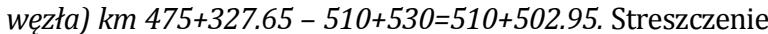
w języku niespecjalistycznym, t. 1, Kraków, 2007, http: //www.eib.org/attachments/pipeline/20090304_nts6_p l.pdf

Słaboń A. 2008. Konflikty społeczne i negocjacje. Wyd. Uniw. Ekon., Kraków.

Stomma P. Odpowiedź na interpelację $w$ sprawie zmiany kształtu węzła autostrady A1 w Żorach-Rowniu (6.09.2006).

Szczypek T., Wach J. 1996. Funkcje przyrodnicze obszarów zagrożonych $w$ korytarzu ekologicznym Odra-Wisła $w$ okolicach Szczejkowic w Parku Krajobrazowego „CKKRW”. Sosnowiec, (maszynopis).

Sztumski J. 1987. Konflikt społeczny. Prace Nauk. Uniw. Śl., 902, Wyd. UŚ, Katowice.

Teister W. Rospuda zarasta, miasto zablokowane. http://gosc.pl/doc/1306024.Rospuda-zarasta-miastozablokowane (26.09.2012).

Wójt Mszany: Nawet minister z wojewodą nie pomogli. Nowiny Tygodnik Regionalny. http://www.nowiny.rybnik.pl /artykul,31299,wojt-gminy-mszana-nawet-minister-zwojewoda-nie-pomogli.html (14.05.2013).

Wroński M. Sąd zastopował autostradę A1. http://forum.gkw24 $\mathrm{pl} /$ viewtopic.php?f=6\&t=157\&start=360 (17.03.2009).

Wywożą odpady z budowy A1, cierpiq drogi. http://bedzin. naszemiasto.pl/artykul/1312689,bobrowniki-wywozaodpady-z-budowy-a1-cierpia-drogi,id,t.html (9.03.2012). 
Zamknięto objazd autostrady A1. Droga jest w tragicznym stanie. http://katowice.gazeta.pl/katowice/1,35063,14417024, Zamknieto_objazd_autostrady_A1_Droga_jest_w_tragicznym. html (9.08.2013).

Zielińska A. Obwodnica Augustowa tylko przez Raczki - obwieścił rzqd. Rolnicy zapowiadaja protesty. http://www. poranny. pl/apps/pbcs.dll/article?AID=/20090328/MAGAZYN/4395 04655 (28.03.2009).
Zuziak Z.K. 1995. Rozwiązywanie konfliktów środowiskowych w gospodarce przestrzennej. [in:] Salomon L.M. i in. (eds.) Gospodarka samorzq̨ów terytorialnych w świetle doświadczeń amerykańskich. Fund. Promocji Czystych Techn. TECHEKO, Łódź. 